\title{
TOOL FOR THE SYNTHESIS OF MECHANISMS OF NEW ENGINES BASED ON DASY
}

\section{DAVID RICHTR}

CTU in Prague, Faculty of Mechanical Engineering, Technická 4, 166 07, Praha 6. Tel.: +420728462851, E-mail: richtrd@gmail.com

\section{SHRNUTÍ}

Článek se zabývá prezentací nástroje pro syntézu mechanismů motoru založený na DASY a jeho využití prì návrhu parametrů experimentálního jednoválcového motoru. Nástroj obsahuje parametrický model motoru založený na DASY. Model umožní simulovat termodynamiku motoru a jeho mechanismy. Skládá ze submodelů, které řeší termodynamiku, kinematiku a dynamiku rozvodového mechanismu, jeho řemenový pohon a hydraulický okruh natáčení vačkových hřídelí. Metodik syntézy mechanismů bylo využito pro nalezení hodnot kalibračních parametrů. Následně byly parametry submodelů validovány experimentálními daty a jejich hodnoty jsou obsaženy v DASY. Ze submodelů byl sestaven model experimentálního jednoválce, který ověruje jeho konstrukci, umožňuje optimalizovat jeho parametry a předpovídat jeho chování v různých simulovaných stavech.

KLIČCVÁ SLOVA: VARIABILNİ VENTILOVÝ ROZVOD, VAČKA, VENTIL, VAČKOVÁ HŘÍDEL, HYDRAULICKÝ PŘESUVNÍK VAČKOVÉ HŘíDELE, SIMULACE, EXPERIMENTÁLNÍ ZÁŽEHOVÝ MOTOR, DYNAMIKA, VÝPOČET, GT-SUITE

\section{ABSTRACT}

The article presents a tool for the synthesis of engine mechanisms based on DASY and the use thereof for designing the parameters of an experimental single-cylinder engine. The tool includes a parametric engine model based on DASY. The model will make it possible to simulate the engine thermodynamics and its mechanisms. It consists of sub-models which deal with the thermodynamics, kinematics and dynamics of the valve timing mechanism, its belt drive, and hydraulic circuit for camshaft adjustment. The methodologies of synthesis of mechanisms were used to determine the values of the calibration parameters. The parameters of the sub-models were subsequently validated by experimental data, and the values thereof are included in DASY. The sub-models were used to assemble the model of an experimental single-cylinder engine which validates the design thereof, makes it possible to optimize its parameters and predict its behavior in different simulated conditions.

KEYWORDS: VARIABLE VALVE TRAIN, CAM, VALVE, CAMSHAFT, HYDRAULIC CAM PHASER, EXPERIMENTAL SI ENGINE, SIMULATION, DYNAMICS, CALCULATION, GT-SUITE

\section{INTRODUCTION AND RESEARCH}

The creation of the model of the single-cylinder parametric model was based on a four-cylinder engine. Parameters of the different parts were available for this engine from CAD models. Data such as valve acceleration curves, actual speed and the forces acting on the rocker arm were available from experiments. The entire parametric model was divided into sub-models which were subjected to calibration according to this available data. A conventional approach to the simulation of the dynamics of the mechanism consists of modeling individual subsystems separately and subsequently using the results of its marginal conditions for another sub-model. It is advisable to approach the analysis of the individual interactions between individual subsystems holistically. It is possible to use commercial or university software. The commercial software includes, for example, GT-SUITE, a Ricardo software suite (Valvedyn, Wave, Engdyn...), or SIMPACK. University software includes, for example, MBSim of the Munich Technical University. Individual solutions are offered by modeling of a system of $1 \mathrm{D} / 2 \mathrm{D} / 3 \mathrm{D}$ bodies using an approach where the bodies can be solid or flexible. The finite element method is used to address the deformations of each body.

Depending on the complexity of the model and the required results, it is important to pick a suitable approach with respect to the time-intensity of the calculations. The advantage of modeling of individual subsystems separately is a greater number of parameters which describe the real model in greater 
detail and contribute to greater capability of calibration of the model with a relatively low time-intensity of the calculation. Synthesis of the individual mechanisms therefore increases the number of parameters which are used for sufficient description of the entire mechanism, and thus the calculation demands. It is necessary to optimize the number of parameters, such as to achieve a reasonable calculation time and describe all important dynamic phenomena. Out of the freely available sources, we can mention - as an example of holistic approach to the synthesis of mechanisms in [1].

The software used for calibration of the parameters of the individual sub-models was DASY as a multi-parametric solver that uses a genetic algorithm.

\section{DESCRIPTION OF THE SUB-MODELS}

The creation of the parametric engine model involved division of the entire model into sub-models. The parameters of these sub-models were calibrated according to the available measurement data; see Chapter 3.

\subsection{THERMODYNAMIC SUB-MODEL}

The thermodynamic sub-model makes it possible to simulate the thermodynamics of the engine such as, for example, a model of the SI combustion, heat transfer to the cylinder walls, fluid dynamics in the pipes. The sub-model can be used for determination of the performance characteristics of the engine, specific fuel consumption, and other parameters. An important capability of the thermodynamic model is determination of the optimal

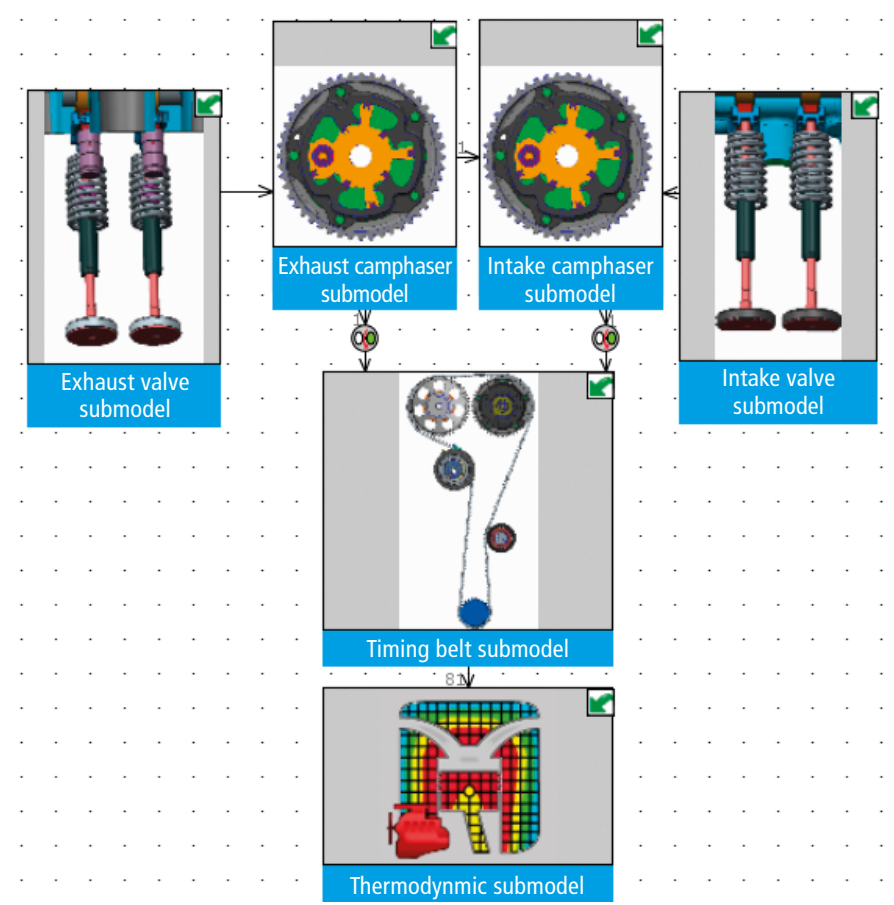

FIGURE 1: Schematic single-engine model in GT-ISE.

OBRÁZEK 1: Schematický model parametrického jednoválcového motoru. timing of the intake and exhaust valves to maximize the torque and minimize consumption, which should ensure reduction of the emissions in the exhaust gases. The determination of the optimal timing must be considered with regard to the design limits of the engine, respecting for example the collision of the piston and the valves.

\subsection{MODEL OF THE INTAKE AND EXHAUST VALVE DYNAMICS}

One of the more sophisticated sub-models for calibration is the model of the intake and exhaust valve dynamics. Their models are identical and only differ by the cam profiles used and input parameters of the individual elements. The specific type of the valve-operating mechanism used in the model is DOHC. For the single-cylinder engine model it includes two intake valves and two exhaust valves. For calibration and acceleration of the calculation time, the sub-model was simplified to include one separate valve in order to find the values of the calibration parameters. The model is described by a total of 37 parameters with which it was calibrated. The calibration parameters are divided into two parts. The first part is physical, input parameters of the elements such as stiffness of the individual parts (valve, rocker arm...) which were determined using the FEM. These parameters remain constant with the changing rotation speed. The second group is parameters of the contact points (Figure 3 ) which are generally used for mathematic transmission of information between the individual elements and the value of which is difficult to determine. It is assumed that they can change with the change of the actual rotation speed. The reason is that some of these elements ensure convergence of the numerical solution. For example, the ramp function of stiffness simulates the flexibility upon contact of two bodies and deals with the step change of stiffness of the contact which would cause the complications in the numerical solution. The model includes an active predictive tribological model dealing with the elastohydrodynamic contact between the individual elements.

\subsection{MODEL OF A TIMING BELT WITH HYDRAULIC CAM PHASER}

The model includes a toothed belt pulley with hydraulic cam phaser on the intake and exhaust side, a toothed belt pulley on the crankshaft, idler and tensioner, and a toothed belt. The GT-ISE environment models a toothed belt as a system of flexible beam elements and rigid bodies in the form of teeth. The beams are considered loaded with axial and shear stress and bending moment. The entire system is discretized using the principle of the finite element method. The number of teeth represents the number of the finite elements which are connected in nodes. In physical terms, the belt consists of a rubber body and steel cord. It is the steel cord that increases the overall stiffness of the belt and reduces the amplitude of inherent oscillation. Based on the density of the composition of the rubber and the steel cord, the 

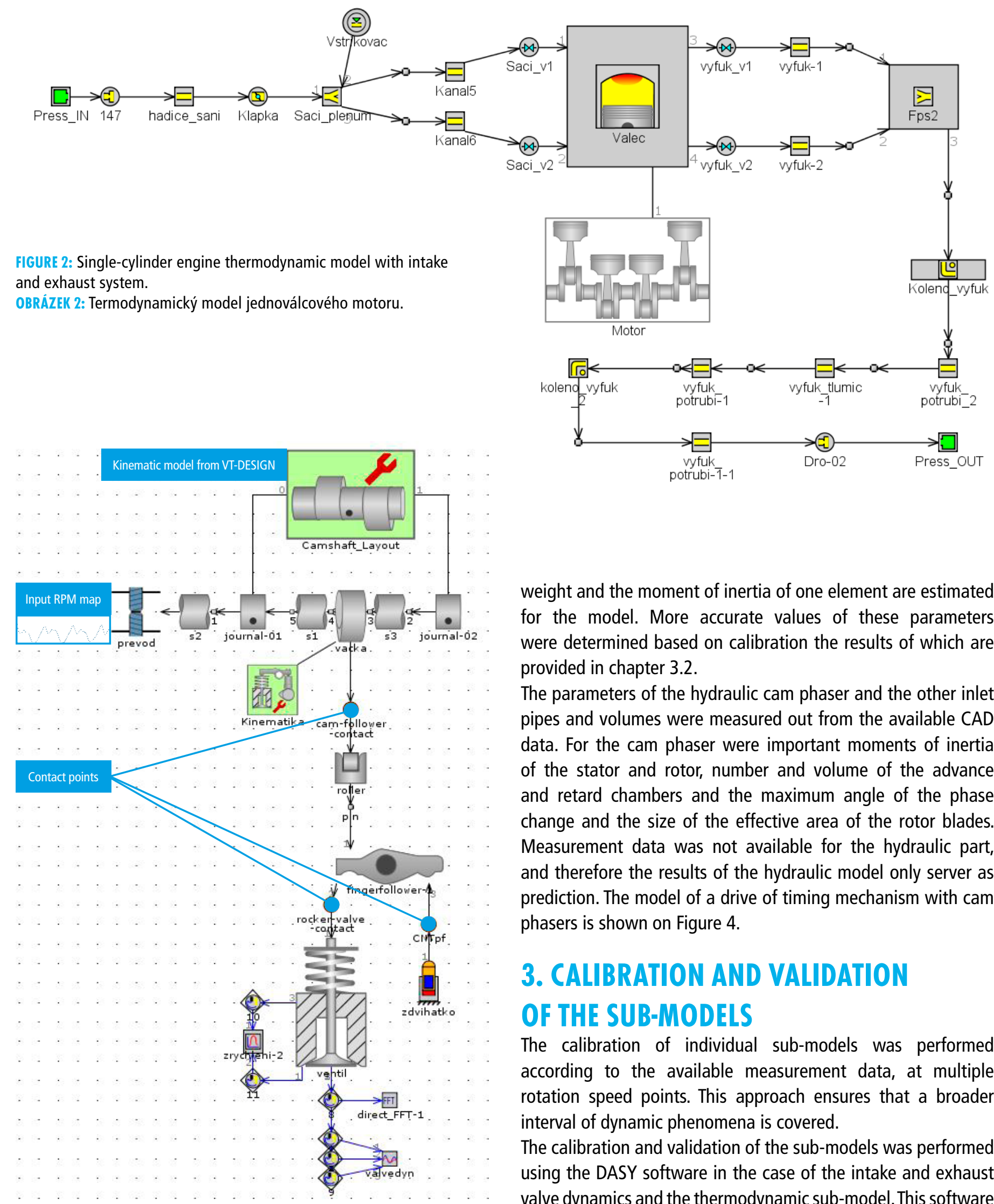

weight and the moment of inertia of one element are estimated for the model. More accurate values of these parameters were determined based on calibration the results of which are provided in chapter 3.2 .

The parameters of the hydraulic cam phaser and the other inlet pipes and volumes were measured out from the available CAD data. For the cam phaser were important moments of inertia of the stator and rotor, number and volume of the advance and retard chambers and the maximum angle of the phase change and the size of the effective area of the rotor blades. Measurement data was not available for the hydraulic part, and therefore the results of the hydraulic model only server as prediction. The model of a drive of timing mechanism with cam phasers is shown on Figure 4.

\section{CALIBRATION AND VALIDATION OF THE SUB-MODELS}

The calibration of individual sub-models was performed according to the available measurement data, at multiple rotation speed points. This approach ensures that a broader interval of dynamic phenomena is covered.

The calibration and validation of the sub-models was performed using the DASY software in the case of the intake and exhaust valve dynamics and the thermodynamic sub-model. This software uses a genetic algorithm which is based on the principle of FIGURE 3: Model of single-valve mechanism. OBRÁzEK 3: Model sacího ventilu. evolution biology and uses processes such as crossbreeding, 


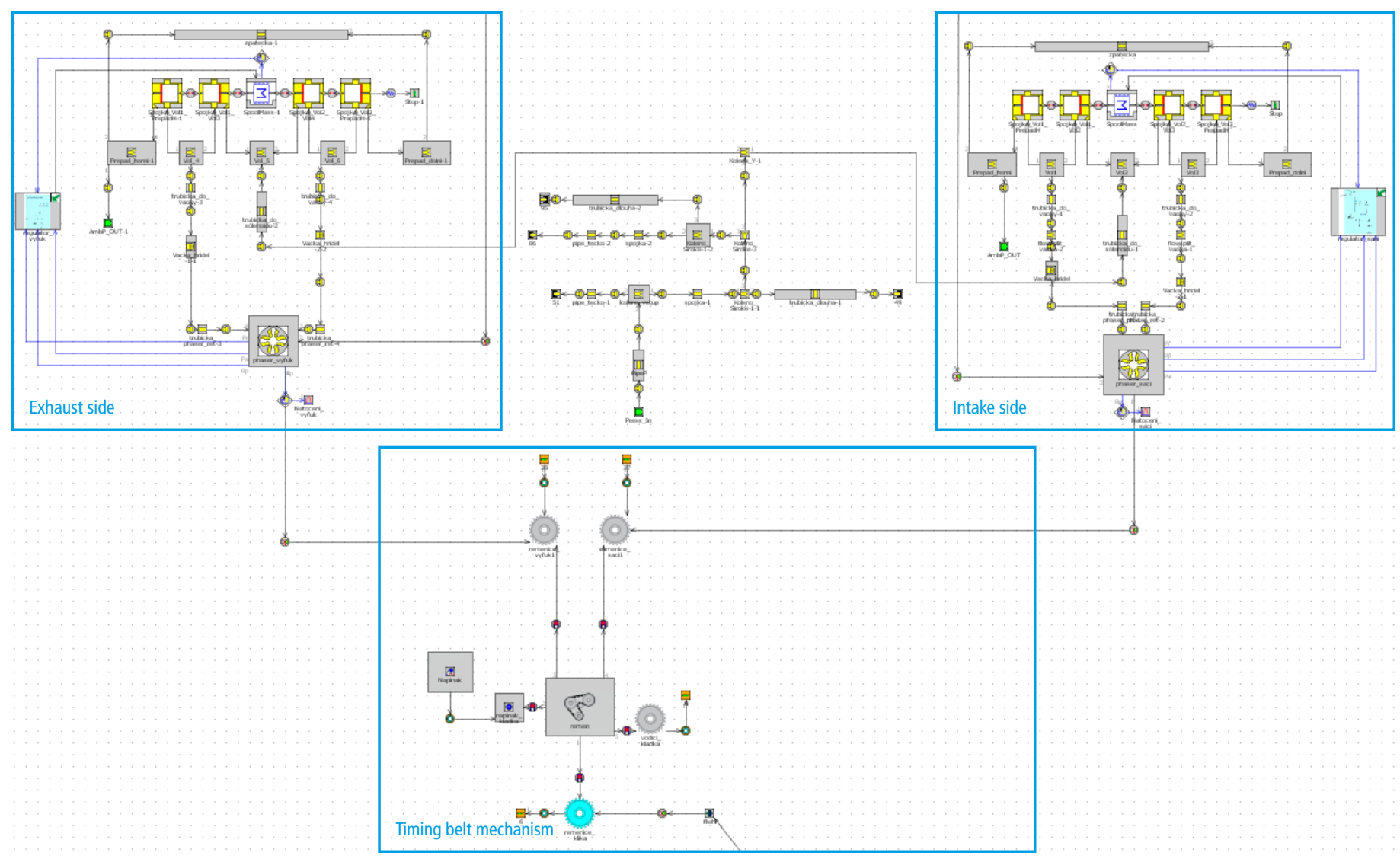

FIGURE 4: Model of timing belt with pulleys and hydraulic cam phaser OBRÁZEK 4: Model řemenového rozvodu a hydraulického camphaseru

mutation, natural selection or hereditability. The advantage of this software is that it solves optimization tasks with many variable parameters and looks for the optimal solution according to the predefined criteria. GT-SUITE includes a program called GT-POST which is used for displaying the simulation results. The results are divided into two types. The first type is display of the calculated values of magnitudes such as continuous function depending on time or angle in one or more operation cycles. The other type is display of the value of the magnitude as a single integral value in the form of average, maximum, minimum, or cumulative value integrated over a cycle. An example is effective mean pressure, average torque, average consumption, etc. This form of result is called RLT.

\subsection{OPTIMIZATION OF THE THERMODYNAMIC MODEL}

Optimization of the valve timing is based on the RLT-type results. The optimization was performed in order to determine the maximum torque along with the minimum specific consumption. The results file of the GT-POST program exports output RLT magnitudes of the specific consumption and torque into a text file. This file, together with the model from GT-ISE, is uploaded to the DASY environment where independent and dependent parameters are chosen. The independent parameters are defined as input values, i.e., starts of valve lift. In addition, an interval is defined in which the input variables should change in order to prevent collision of the piston and valves. The dependent parameters are output magnitudes, i.e., values of the specific consumption and torque. A sample of the parameter settings together with a simple flowchart is shown on Figure 5 .

The output is a set of results from which the compromise between the maximum torque and minimum consumption must be selected manually. In addition, it is necessary to respect

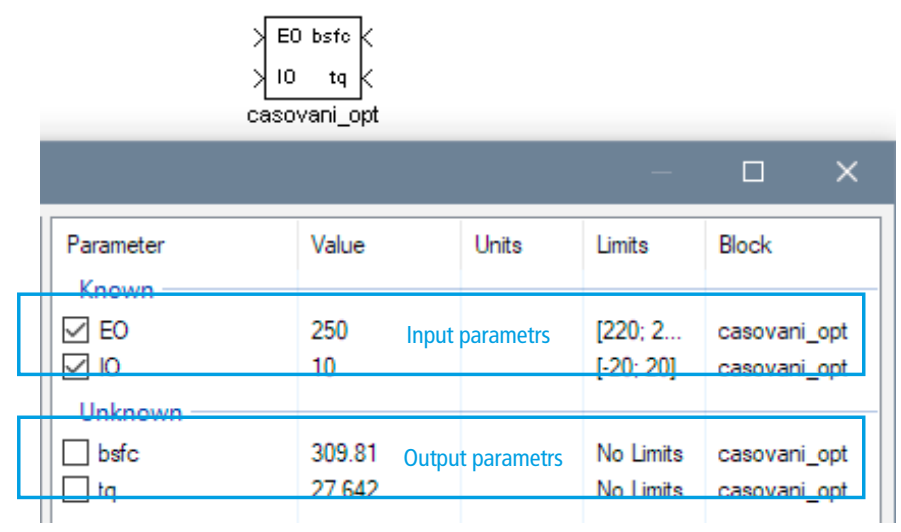

FIGURE 5: Setting the known and unknown parameters in DASY OBRÁzEK 5: Nastavení známých a neznámých parametrů v DASY 
TABLE 1: Results of valve timing optimization

TABULKA 1: Výsledky hodnot optimálního časování ventilů

\begin{tabular}{|c|c|c|}
\hline RPM & IO before TDC [CA] & EO before BDC [CA] \\
\hline 1000 & 17 & 29 \\
\hline 2000 & 16 & 37.5 \\
\hline 3000 & 14 & 42 \\
\hline 4000 & 13 & 28 \\
\hline 5000 & 10 & 25 \\
\hline 6500 & 2 & 24 \\
\hline
\end{tabular}

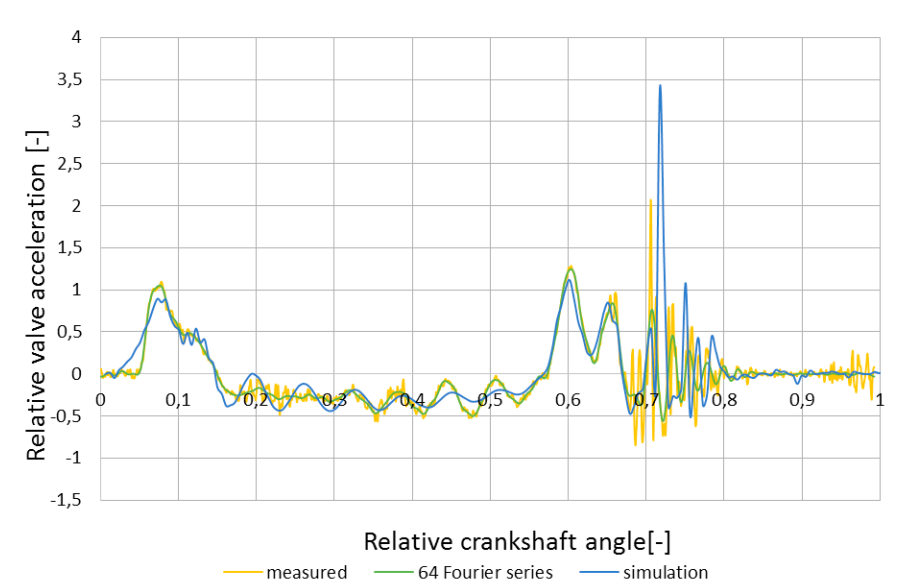

FIGURE 6: Comparison of simulation and measured data for intake valve acceleration

OBRÁZEK 6: Srovnání simulace a měření zrychlení sacího ventilu

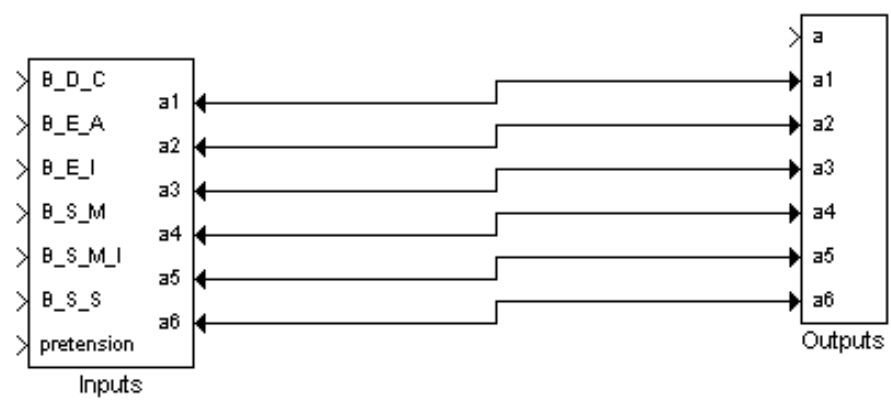

FIGURE 7: Flowchart for calibration of the rotation speeds of camshafts in DASY FIGURE 7: DASY set for camshaft RPMs

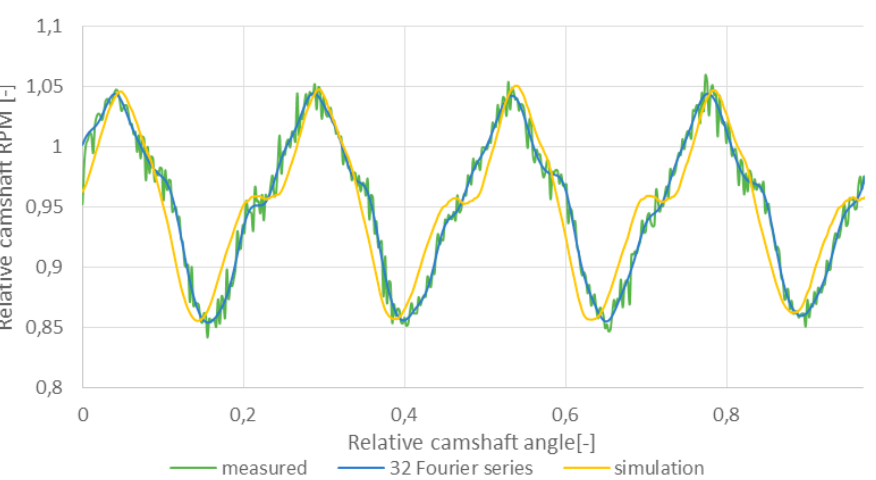

FIGURE 8: Comparison of the intake camshaft RPM from simulation and from measurement

OBRÁZEK 8: Porovnání průběhu okamžitých otáček na sací vačkové hřídeli ze simulace a měření the rotation speed of the engine for which the optimization was performed. The optimal timing determined for the version used in this model, i.e., single-cylinder, unsupercharged engine with external formation of the mixture, is shown in Table 1. The optimization was performed for maximum engine load.

\subsection{CALIBRATION OF THE DYNAMICS OF THE INTAKE AND EXHAUST VALVE}

Calibration of the dynamic characteristics of the valve train mechanism was also performed using the DASY software. The process and evaluation of the calibration is identical as in the case of [3]. For the evaluation of the objective function, the genetic algorithm searched for the minimum value of the sum of the squares of the deviations between the objective function and the current curve from the simulation at the reference points. The deviations were observed on the valve acceleration curve in the time and frequency domain.

The measured curve was decomposed by Fourier transform into 64 harmonics where 15 reference points were determined (see [3]).

\subsection{CALIBRATION OF THE TIMING BELT TRANSMISSION}

Curves of actual rotation speed from the measurement and from the simulation results were compared in the toothed belt mechanism. As stated above, the material properties of the belt were used as parameters for calibration.

The available data from the measurement, however, was for a four-cylinder engine, not for the single-cylinder engine under review. Therefore, an auxiliary, purely mechanical model of four-cylinder engine was built. This model was composed of the timing mechanism and intake and exhaust camshaft where the data from chapter 2.2 was used as the values of the valve mechanism parameters. This model was used only for more accurate determination of the toothed belt parameters. The basic material properties and the nominal pretensioning of the belt were determined by an estimate, and the more accurate value thereof was determined by calibration. The identical process was used as in the calibration of valve acceleration. In this case, however, there was sufficient decomposition into 32 harmonics using Fourier transform of the actual rotation speed of the camshafts and only 6 reference points because the curve is periodical. The diagrammatic model from the DASY environment is shown below. The model includes the input parameters in the form of the material properties of the belt and the pretensioning thereof. The output is the reference points on the decomposed curve of the actual rotation speed.

The best match was achieved at $2000 \mathrm{rpm}$. The parameters corresponding to this curve were used in the other rpm points. The value of the nominal pretensioning of the toothed belt was based on simulation of $253 \mathrm{~N}$. According to the available 
information, this value ranges between $305 \div 380 \mathrm{~N}$ in a real four-cylinder engine. This can be considered sufficiently accurate approximation to reality, to which also the below-pictured curve of the actual rotation speed corresponds.

\section{REFERENCE RESULTS OF THE PREDICTIVE MODEL}

Connection of the sub-models resulted in a predictive model of a single-cylinder engine which was used for calculations supporting the design of the parameters and design of a real engine. The parameters obtained from the auxiliary calibration sub-models were put in this predictive model for each rotation speed point. They are parameters of the toothed belt, the intake and exhaust valves. The predictive model of a virtual single-cylinder engine can be used also for prediction of the behavior of a real engine in different conditions which cannot yet be performed on a real engine as it is still under development. This can prevent conditions in which the timing elements would be damaged.

A synthesis of the thermodynamic and mechanical model can be used to predict the load upon the timing system parts. The mechanical model provides the thermodynamic model with information on the lift curves and, on the other hand, receives information on the curve of the pressure in the channels, in the cylinder, and temperature gradients, which includes these influences on the calculation of the dynamics of mechanisms.

The following three sub-chapters include the reference results of the single-cylinder engine. This data has not yet been validated experimentally.

\subsection{DETERMINATION OF THE MAXIMUM ROTATION SPEED}

The determination of the maximum rotation speed ( $r p m)$ of the timing mechanism is based on the monitoring of the valve lift curve and dynamic influences. The limit condition is one where the masses of the timing mechanism are accelerated and the valve spring is excited with a frequency approximating its natural frequency. At this moment the spring loses its pre-tensioning and ability to close the valve in accordance with the defined cam profile. The valve seating velocity is also higher than the pre-scribed velocity, and valve separation occurs. This condition is undesirable because it increases the load and wear and tear of the entire mechanism. One of the possible methods to determine the limit rotation speed is monitoring and comparing the kinematic and dynamic lift curve of the valve. In the optimal scenario, the dynamic lift curve is lower than or equal to the kinematic curve due to the flexibility and stiffness of the different parts. To determine the valve separation from the seat, the Valve Separation element was used. It is element, which compares difference between dynamic and kinematic valve lift. The positive value of valve

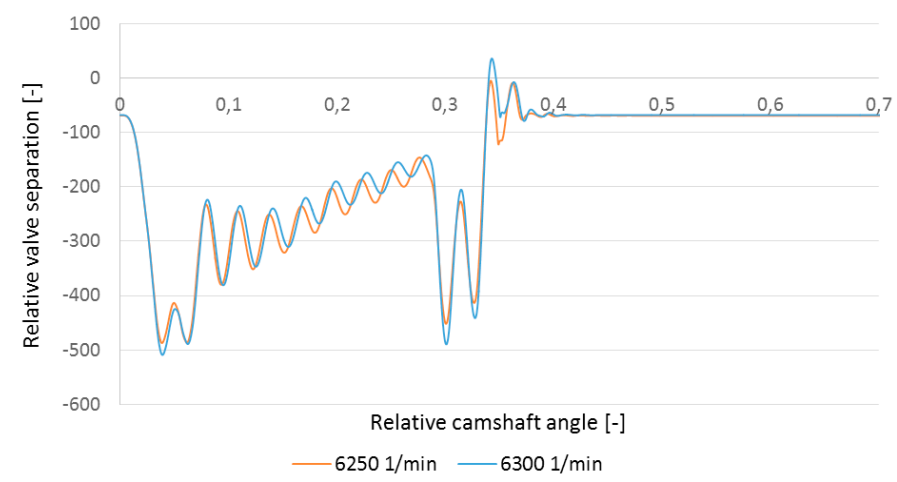

FIGURE 9: Valve separation dependence on relative camshaft RPM OBRÁzEK 9: Průběh odskoku ventilu od sedla v závislosti na otáčkách vačkové hř́dele

separation (exceeding zero value) represents the separation of the valve from the seat. Based on the analysis of this curve, the maximum operating rotation speed of the valve train was determined. The chart below shows the curve of valve separation at the rotation speed limit where no separation occurs yet. After having exceeded this value, separation occurs after valve seating (the critical zone is depicted in red). It is the first identifiable condition where stroke occurs in the valve seat. The valve train, however, can be operated further up to higher speed because the limit value of valve separation is determined by the design limits of the mechanism. For example it means the maximum possible gap between valve and valve seat after valve bounce defined by designers. Valve seating velocity gradient increases with the increasing rotation speed, which is also associated with excitation of the valve spring. As I have stated above, due to the loss of pretensioning of the valve spring by the excitation with natural frequency the valve separation is not absorbed by the spring. This results in increased stress on the entire valve train.

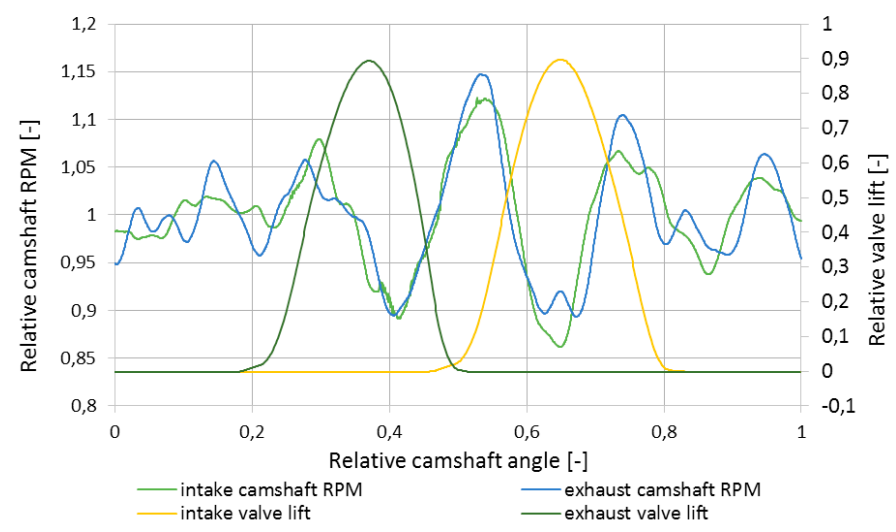

FIGURE 10: Valve lift curves and the impact on the actual rotation speed of the camshaft

OBRÁZEK 10: Průběh zdvihových křivek ventilů a vliv na průběh okamžitých otáček vačkové hřídele 


\subsection{ACTUAL ROTATION SPEED CURVE}

The actual rotation speed curve periodically oscillates around the mean value of relative rotation speed of the camshaft. The action of the exhaust cam on the valve overcomes the pre-tensioning of the valve spring and reduces the actual rotation speed. Upon closure of the valve, the pre-tensioning in the spring increases the rotation speed. The same principle operates in the intake valves. After they have been closed, the actual rotation speed stabilizes around the mean value, which is manifested by decrease of the amplitude thereof. A partial test was performed because of the impact of the oscillation of the actual rotation speed in the region of closing of the valves, whether more significant deviations occur. No greater oscillation of the belt occurs, according to Figure 10, in the deviation of the amplitude of the actual rotation speed from the value of mean rotation speed in the region outside of the valve lift. It means the sufficient value of pretensioning of the toothed belt, which can be used to predict good adjustment thereof.

\subsection{INTERRUPTION OF THE SUPPLY OF PRESSURE OIL}

One of the possible conditions in which a single-cylinder engine can be found is a condition of certain failure. For example, in an experimental test, the oil circuit may be interrupted and the pressure jumps to a lower value. The mechanism includes a hydraulic cam phaser which is operated by pressure oil. Upon the loss of oil pressure, the valve timing may change, leading to a collision of the piston and valve in the event that the cam phaser rotor is not locked by a pin. Therefore in the design of the mechanism, it is necessary to take this risk into account and set the range of the cam phaser and valve timing such that a collision of the piston and valve can never occur. Decrease in oil pressure in the cam phaser chambers adds a degree of rotor freedom of the system between the stator and blades of the rotor of the cam phaser. The chart below shows the curve of the phase change of the cam phaser in the event of a step change of the oil pressure. The added degree of freedom of the mechanism between the pulley and camshaft causes a phase change due to the momentum transmitted through the pulley and the angular momentum of the system. Decreasing angular speed due to valve springs can cause overturning of the rotor blades against the stator between its walls. This will result in chaotic actual rotation speed of the pulley or, more precisely the camshaft.

The type of failure where the rotor oscillates against the stator due to the sudden drop of oil pressure and, at the same time, the pin locking does not occur is very unlikely. But if it happens, it will have impact on the entire mechanism. According to Figure 11, there is an apparent oscillation of the phase change of the cam phaser after oil pressure loss in a very short time interval. One of the effects of this cause is the form of the resulting lift curve in comparison with the kinematic curve. This difference is shown on the picture below. The separation of dynamic from kinematic lift means greater valve acceleration than the one for which the mechanism is designed. In the first lift curve we can observe greater separation, which is also associated with the impact of the rocker roller all the way to the base of the cam. The spring does not manage to absorb the impact of the valve, and an additional valve separation occurs.

Therefore, only from mechanical point of view a short-term interruption of oil supply is not dangerous because increased stress of the individual parts, such as valves, valve seats etc., only occurs locally. But on the other hand, total oil pressure interruption is dangerous for whole engine, if engine does not stop as soon as possible. With this phenomenon is connected secondary problem, which is the deviation of the lift curve from the required curve. See Figure 12.

\section{CONCLUSION}

The article presented the application of a tool for synthesis of engine mechanisms based on DASY. The application includes creation of a computer parametric model of variable valve train with toothed belt, and a thermodynamic model of a single-cylinder engine in the environment of the GT-SUITE software. DASY software with genetic algorithm was used

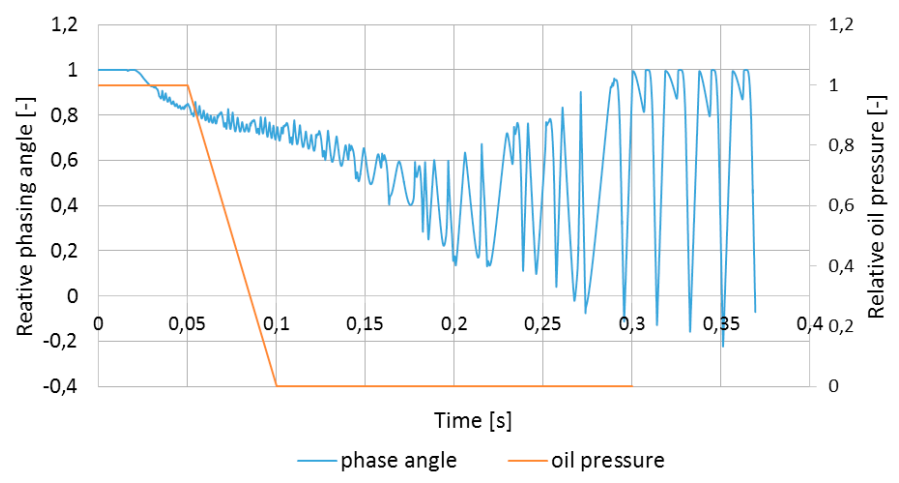

FIGURE 11: Dependence of cam phaser phase angle on oil pressure OBRÁZEK 11: Závislost fázové změny camphaseru na tlaku oleje

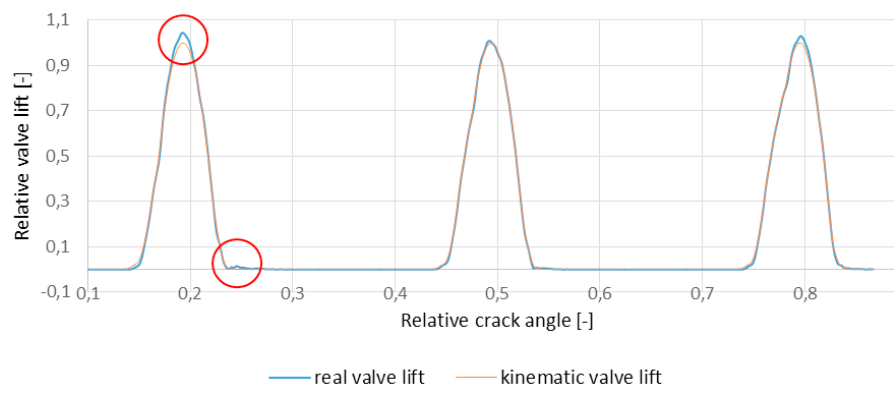

FIGURE 12: Impact of oil pressure loss on valve lift curve OBRÁZEK 12: Vliv poklesu tlaku oleje na zdvihovou křivku ventilu 
for calibration and optimization of the model. The optimal approach seems to be looking for the objective function of the continuous function such as valve acceleration or actual rotation speed curve using a set of reference points and evaluation using the method of minimum value of the sum of the squares of the deviations. Calibration of individual models according to the data measured is more time-intensive also after having used certain simplifications, but a connection thereof leads to the resulting model with a relatively accurate predictability. The holistic approach to the mechanical part of the model seems beneficial in terms of examination of the mutual interactions between the mechanism members. With respect to the uniqueness of the prototype of the experimental engine, the computer model is a useful tool because it makes it possible to simulate conditions which cannot be performed on a test engine because it is still under development. Some design modifications can be made, if applicable. Last but not least, the simulation can prevent conditions where damage could occur to the engine, a fact that has been verified also by several predictive simulations.

\section{ACKNOWLED GEMENTS}

This work was supported by:

- Technological Agency, Czech Republic, programme Centre of Competence, project \#TE01020020 Josef Božek Competence Centre for Automotive Industry.

- The Ministry of Education, Youth and Sports program NPU I (LO), project \# L01311 Development of Vehicle Centre of Sustainable Mobility.
LIST OF NOTATIONS AND ABBREVIATIONS

DASY Design Assistance System

B_D_C Belt Damping Coefficient

B_E_A Belt Axial Stiffness

B_E_I Belt Bending Stiffness

B_S_M Belt Sectional Mass

B_S_M_I Belt Sectional Moment of Inertia

B_S_S Belt Shearing Stiffness

BSFC Break Specific Fuel Consumption

DOHC Double Over Head Camshaft

EO Exhaust Valve Open

I0 Intake Valve Open

RPM Revolution Per Minute

TQ Torque

SI Spark Ignition

\section{REFERENCES}

[1] FISCHER, Thomas a Benjamin SCHAAL. Holistic Design of a cam phaser [online]. In: 2015, s. 28 [cit. 2017-03-19]. Available from: https://www.gtisoft.com/wp-content/ uploads/2015/11/Holistic_Design_Of_A_Cam_Phaser.pdf

[2] GT-ISE Help, GT-SUITE version 2016, Gamma Technologies Inc., 2015

[3] TICHÁNEK, Radek. Dasy Based Tool for The Design of Ice Mechanisms. Journal of Middle European Construction and Design of Cars. 2015-01-1, 13(3), doi: 10.1515/mecdc-2015-0013. ISSN 1804-9338.

[4] RICHTR, David. Výpočet dynamiky variabilního ventilového rozvodu [Calculation of the variable valve train dynamics]. Praha, 2017. THESIS (by Ing.). Czech Technical University in Prague. Faculty of Mechanical Engineering, Department of Automotive, Combustion Engine and Railway Engineering. Supervisor: Radek Tichánek. 